ZNCB IM. EDYTY STEIN • FENOMEN EDYTY STEIN - DAS PHÄNOMEN EDITH STEIN NUMER $11 \quad$ POZNAŃ 2014

\title{
Andrzej Półtawski
}

\section{RACJONALNOŚĆ FILOZOFII EDYTY STEIN}

\begin{abstract}
Poznawcze uprawomocnienie pochodzi ostatecznie nie z samej bezpośredniości, oczywistości lub wiarygodności, lecz z maksimum koherencji ze wszystkimi odpowiednimi względami, włączając $\mathrm{w}$ to wszystkie odpowiednie intuicyjnie wiarygodne dane ${ }^{1}$.
\end{abstract}

Ernest Sosa

Znaczna część filozofów nowożytnych przyjęła podstawowe założenia Kartezjusza i stosowała je w kontekście analitycznego nastawienia empiryzmu brytyjskiego. Dwa dwudziestowieczne odgałęzienia kartezjanizmu - filozofia analityczna i fenomenologia - poświęciły się analizie odpowiednio dwu sfer, ostro odciętych od siebie przez Kartezjusza: res extensa i res cogitans - świata materialnego i świadomości. Obie te szkoły wyszły jednak w swej teorii poznania z sensualistycznej i atomizującej koncepcji "danych zmysłowych".

Jednym z głównych motywów fenomenologii Husserla, inicjatora ruchu fenomenologicznego i nauczyciela Edyty Stein, było obalenie naturalizmu i scjentyzmu nastawionej na opanowanie świata materialnego „kartezjańskiej nauki”, przezwyciężenie wąskiego, przyjętego przez nią rozumienia doświadczenia poprzez zbudowanie, jak to sformułował Husserl, „najbardziej uniwersalnego i konsekwentnego empiryzmu, który na miejsce ograniczonego «doświadczenia» empirystów kładzie pojęcie w sposób konieczny rozszerzone, pierwotnie prezentującą naoczność"2.

1 E. Sosa, Classical Analysis, cyt. za: T. Szubka, Filozofia analityczna, metody, ograniczenia, Wrocław 2009, s. 107

${ }^{2}$ Husserliana, t. IX, Phänomenologische Psychologie. Vorlesungen Sommersemester 1925, s. 254, cyt. za: S. Strasser, Welt im Widerspruch, Gedanken zu einer Phänomenologie als ethischer Fundamentalphilosophie, Dordrecht-Boston-London 1991 (Phaenomenologica t. 124), s. 3. 
Filozofia miała więc, przynajmniej w pierwotnym, „oficjalnym” ujęciu:

1. Opierać się na źródłowym, bezpośrednim, naocznym doświadczeniu wszelkich dostępnych nam bytów.

2. Takie podejście miało dać filozofii niewzruszone podstawy, absolutną pewność apriorycznego uchwycenia istoty tych bytów. Filozofia miała być „nauką ścisłą".

3. Ponadto, po pierwszej wojnie światowej Husserl wyraźnie podkreślał, że uprawianie filozofii „ma filozofowi pozwolić dostrzec ostateczną rzeczywistość i prowadzić życie w pełni prawdziwe"3, zgodne $\mathrm{z}$ rozumem, co wymaga oczywiście zrozumienia nas samych i świata, w którym żyjemy i działamy, ukazania sensu świata i naszego życia, a więc dotarcia do ostatecznej prawdy - co dopiero pozwolić może na rozumne życie i działanie. Jest to zadanie etyczne, zakładające przede wszystkim opracowanie filozoficznej antropologii, zajęcie się ludzką osobą w kontekście świata, w którym ona żyje.

Jak Husserl i związani z nim fenomenologowie próbowali zrealizować te postulaty?

Źródłowość, a zarazem pewność doświadczenia miało umożliwić opisywanie przeżyć świadomych, elementów „strumienia czystej świadomości", kartezjańskiego cogitare jako czegoś w pełni rozpościerającego się przed filozofującym. Husserl uważał, że można do niego dotrzeć, stosując transcendentalną redukcję, i uznał początkowo czystą świadomość za „W sobie zamkniętą [...] całość bytu absolutnego, w którą nic nie może wtargnąć i z której nic nie może się wymknąć" 4 .

W swych późnych rozważaniach Husserl zdał sobie jednak sprawę z tego, że nauka nie interesuje się samą działalnością naukowców, dokonującą się w „świecie, w którym żyjemy”, od którego nauka właśnie abstrahuje i przypisuje badanie tej sfery fenomenologii. Uczynienie prawdy nauki przyrodniczej przejrzystą wymaga nauki o duchu, który tę prawdę wytwarza. Sama przyroda ma tu zostać wprowadzona w sferę ducha. Nie może to jednak być dokonane przy pomocy, jak się wyraża Husserl, „substrukcji teoretyczno-logicznych” „nauki obiektywnej”. Ma to więc być zupełnie nowy rodzaj nauki 5 .

3 Husserliana, t. VIII, cyt. za: L. Landgrebe, Faktizität und Individuation, Studien zu den Grundfragen der Phänomenologie, Hamburg 1982, s. 29.

4 E. Husserl, Idee czystej fenomenologii i fenomenologicznej filozofii, t. I, tłum. D. Gierulanka, Warszawa 1967, s. 93.

5 Zob. W. Biemel, Reflexionen zur Lebensweltthematik, w: Phänomenologie heute, Festschrift für Ludwig Landgrebe, red. W. Biemel, Haag 1972, s. 49-77, oraz mój artykuł Fenomenologia jako 
W toku kolejnych prac fenomenologów, w tym samego Husserla, okazało się, że - z jednej strony - strumień świadomości nie mógłby istnieć bez posiadanego przez podmiot modelu świata, który dopiero nadaje mu sens, że nie można odseparować owego modelu od strumienia świadomości. $\mathrm{Z}$ drugiej zaś strony, zdano sobie sprawę $\mathrm{z}$ tego, że - jak to $\mathrm{w}$ ostatnich dniach swego życia napisał Ingarden - „podmiot poznający ma bezpośredni dostęp do różnych od siebie (swego Ja) istności, jeżeli w ogóle ma być podmiotem poznającym" 6 .

Praca badawcza Edyty Stein zaczęła się od pokazania, że mamy taki dostęp do innych osób i ich życia. Zaś w swym głównym dziele Byt skończony i byt wieczny określiła ona teren badań filozoficznych jako „pole świadomości w sensie życia naszego Ja [podkr. A.P.]"7. Tematem jest więc całe życie osób ludzkich - życie, które trzeba przecież uznać za coś znacznie szerszego niż „strumień przeżyć” czy „czysta świadomość”.

Centralnym wątkiem tego dzieła jest obszerna teoria sensu, bytu istotnościowego, ze specjalnym naciskiem na hierarchiczny porządek, scholastyczne ordo, zapewniający temu, co istnieje, zrozumiałość w kontekście całości bytu. Autorka pisze: „Duch jest sensem i życiem - w pełnym urzeczywistnieniu życiem wypełnionym sensem”. W innym miejscu zaś: „Do bytu jako całości należy, że jest całością uporządkowaną, że każde poszczególne jestestwo w niej ma swoje miejsce i swe określone stosunki z wszystkimi innymi; uporządkowanie stanowi element (tak rozumianego) bytu, a jego jawność albo przyporządkowanie do ducha [...] jest częścią tego porządku"9.

Ernst Tugendhat ukazał istnienie w fenomenologii Husserla konfliktu między motywem "krytycznym” a "dogmatycznym”. Każdy z tych motywów prowadzi do zupełnie innej teorii poznania. „Dogmatyczny” związany jest z przyjęciem istnienia „czystej świadomości” jako sfery wiedzy absolutnej, twierdzenia o której i o każdym z jej elementów nie wymagają już żadnego dalszego uzasadnienia. Motyw "krytyczny” jest programem analizy wszelkich doświadczeń dla ich stopniowego rozjaśniania i wynika z przekonania, że wszelkie dane doświadczenia wzajemnie się oświetlają i motywują. Motyw „dogmatyczny” prowadzi do koncepcji pełnej zależności wyższych warstw sensu od jego najniższych elementów, to jest do podejścia

badanie fundamentalne opublikowany w: A. Półtawski, Po co filozofować?, Warszawa 2011, s. 353364.

${ }^{6}$ R. Ingarden, Studia z teorii poznania, oprac. A. Węgrzecki, Warszawa 1995, s. 11.

7 E. Stein, Byt skończony a byt wieczny, tłum. J.I. Adamska OCD, Poznań 1995, s. 68.

8 Tamże, s. 391.

9 Tamże, s. 318. 
atomizującego, motyw "krytyczny” - do całościowego, holistycznego ujęcia wiedzy i rzeczywistości $i^{10}$.

Przytoczone cytaty świadczą o tym, że Edyta Stein opowiada się wyraźnie za motywem "krytycznym". Jak zatem widzi ona teoretyczny status filozofii? „Ścisłość" filozofii polega według niej na tym, że jest to poważne i racjonalne rozważanie. Ale - jak widzieliśmy - już Husserl uznał filozofię za dyscyplinę zupełnie nowego rodzaju - naukę o duchu, zajmującą się sferą „świata, w którym żyjemy”, wcześniejszą teoretycznie od wszelkich rozważań nauki.

Robert Spaemann przeciwstawił filozofię naukom według łacińskiego przysłowia ars longa, vita brevis. Nauka budowana jest wiekami przez wysiłek pokoleń, filozofia dotyczy naszego krótkiego życia i musi podjąć decyzję co do jego sensu i kierunku. Od filozofii - pisze Spaemann - oczekujemy pomocy $\mathrm{w}$ porozumiewaniu się co do celów działania i reguł działanie ograniczających ${ }^{11}$.

Życie ludzkie to odczuwanie, myślenie i działanie. Do uzasadnienia działania nie wystarczą jednak hipotezy, formułowane przez naukę $\mathrm{w}$ odniesieniu do jej problemów - hipotezy, które są zawsze w pewnym sensie partykularne. Filozofia chce objąć całość rzeczywistości, podnosi roszczenie do totalności. Nie ma tu miejsca na hipotezy, ponieważ nie ma kryteriów ich obalenia, pozostają więc tylko twierdzenia apodyktyczne.

Filozofia jest refleksją absolutną, nauki próbami redukcji. Ale istnieje określone wymaganie co do postawy filozofa: racjonalność, rozumiana jako własność podmiotów, nie zaś jako oderwana od nich struktura, jako szukanie argumentów i dążenie do eliminacji wpływu na myślenie wszelkich interesów. To też Spaemann mówi o cnocie racjonalności, która ma cechować filozofa.

Wydaje się, że takie pojęcie filozofii dobrze pasuje do poglądów Edyty Stein, która chce budować filozofię jako mądrość. Uzasadnienie nie polega tu ani na dedukowaniu twierdzeń z pewnego układu aksjomatów, ani na budowaniu większych całości z absolutnie poznanych elementów, lecz, jak napisał w tekście, który przyjąłem za motto niniejszego odczytu, Ernest Soza, na „maksimum koherencji ze wszystkimi odpowiednimi względami, włączając $w$ to wszystkie odpowiednie intuicyjnie wiarygodne dane". Odpowiada to przyjętej przez Edytę Stein za tradycją (między innymi tomistyczną) hierarchicznej strukturze bytu.

${ }^{10}$ E. Tugendhat, Der Wahrheitsbegriff bei Husserl und Heidegger, Berlin 1970, s. 194 i n.

${ }^{11}$ Zob. R. Spaemann, Kroki poza siebie, tłum. J. Marecki, Warszawa 2012. 
W świetle tego stwierdzenia nasuwa się jednak pewna wątpliwość w odniesieniu do przedstawienia przez Edytę Stein struktury bytu istotnościowego, a mianowicie umieszczenia przez nią na najwyższym szczeblu tego bytu prostych momentów istotnościowych. Czyż nie jest to pewien relikt prowadzący do takiego kawałkowania "motywu dogmatycznego"? Czyż nie wydaje się znacznie bardziej przekonującym przyjęcie, że Bóg, tworząc sensowną, istotową strukturę świata, stworzył ją od razu jako całość - zwłaszcza wobec tak podkreślanego przez Edytę Stein motywowania się i wzajemnego oświetlania wszelkich elementów i aspektów tego świata, świata charakteryzującego się analogicznością i wielorakimi powiązaniami oraz wzajemnymi zależnościami występujących w nim bytów?

Jest rzeczą oczywistą, że filozofia, która ma kierować życiem człowieka, musi zastanowić się nad wszystkim, co na to życie może wpływać, a więc a nawet, powiedzieć trzeba, przede wszystkim - nie może nie uwzględnić Boga. Głosy, które zarzucały takiej filozofii łączenie heterogenicznych wątków, nie brały pod uwagę tego jej podstawowego rysu i związane były przede wszystkim z podkreślonym przez Karola Wojtyłę kosmologizmem arystotelizmu. $W$ tak rozumianej filozofii argumentem jest cały porządek sensu, który, patrząc dość uważnie i z obowiązującą filozofa bezstronnością, możemy wypatrzeć w naszym świecie.

Wyniki osiągnięte przez modernę dodatkowo tę konieczność wzmacniają. Filozofia nowożytna pokazała mianowicie, że kartezjańska nauka nie potrzebuje czegoś takiego, jak prawda - pojęcia, które miałoby rację bytu jedynie w przypadku istnienia Boga. Okazuje się więc, że mamy tylko dwie możliwości: zaprzeczyć wraz z postmodernistami istnieniu wszelkiego sensu i wszelkiej prawdy lub przyjąć Boga jako jej gwaranta. Czy jednak dziś, po doświadczeniach ostatniego stulecia i rozpaczliwym głosie z gułagu Andrieja Donatowicza Siniawskiego: „Przyszedł czas, aby pomyśleć o Bogu”12, możemy sobie pozwolić na uznanie rozważań o Bogu za nieracjonalne?

Spaemann zauważył, że najlepszym wyrażeniem sedna nowożytnego światopoglądu jest zdanie Hume'a „nigdy naprawdę nie wyjdziemy ani na krok poza nas samych"13. Cytowana wyżej Husserlowska charakterystyka „czystej świadomości" jest właściwie trawestacją tego zdania. Widać więc, jak daleką drogę miał Husserl do przebicia się z tej pułapki ku światu, w którym żyjemy - i przyznać trzeba, że przeszedł spory jej odcinek, choć nie wyciągnął ze swych odnośnych rozważań ostatecznych wniosków.

12 A.D. Siniawski, Eine Stimme im Chor, Frankfurt am Main 2009.

13 D. Hume, Traktat o naturze ludzkiej, t. 1, tłum. Cz. Znamierowski, Warszawa 1963, s. 95. 
Edyta Stein, zwróciwszy się ku teocentrycznej filozofii św. Tomasza, mogła od razu jasno dostrzec tę pułapkę i wyjść z niej. Toteż ukazała ona szeroki obraz hierarchicznie uporządkowanego bytu z Bogiem - Stwórcą i Ojcem - u szczytu; obraz, w którym mogła uwzględnić całą dynamikę wspieranego przez Łaskę rozwoju człowieka. Obraz ten uzasadnia się sam zwartością swego sensu.

Taka wizja wszystkiego, co istnieje, zgodna jest zasadniczo zarówno z określeniem przez Karola Wojtyłę zadania ludzkiej osoby jako rozwijanie się moralne poprzez czynienie dobra, jak i z rozumieniem przez Stephana Strassera fenomenologii jako fundamentalnej filozofii etycznej ${ }^{14}$.

\section{The Rationality of Edith Stein's Philosophy}

\section{Summary}

Starting from Ernst Tugendhat's discrimination of the 'dogmatic' and the 'critical' motive of Husserl's epistemology, the author argues that the former leads to an atomistic, analytic theory of 'pure consciousness', while the latter needs to be developed by holistic approach, in which the cognitive justification - as Ernest Sosa put it - derives ultimately not from direct obviousness or plausibility alone but from maximum coherence with all relevant considerations, including all relevant intuitively plausible data. In the centre of Edith Stein's philosophy lies an elaborate theory of sense showing a hierarchical order of beings. This seems to involve just the 'critical' attitude. Yet, if this is correct, Stein's understanding of the 'moments of essence' as constituting the upper layer of the order of sense seems to be a relic of the Husserlian 'dogmatic', atomistic motive.

${ }^{14}$ S. Strasser, dz. cyt.; zob. też: A. Półtawski, Fenomenologia jako fundamentalna filozofia moralna wedtug Stephana Strassera, w: tegoż, Po co filozofować?, dz. cyt., s. 330-352, oraz: tenże, Fenomenologia a zrozumienie, kim jesteśmy, „Kwartalnik Filozoficzny” 2013, nr XLI , z. 3, 2013, s. 5-18.

Komentarz [T1]: Tutaj pozwalam sobie dokonac glębszej zmiany, ponieważ dotartam do oryginalnej pracy Ernesta Sosa (w abstrakcie jest Soza, to błąd), która jest tu cytowana za kimś innym po polsku. Oryginał jest własnie po angielsku 